\title{
Biological Risks Associated with Fermented Diary Products, Fruits, Vegetables and Meat: A Critical Review
}

\author{
Chukwuma Stephen Ezeonu ${ }^{1 *}$ and Ngozi Cynthia Ezeonu ${ }^{2}$ \\ ${ }^{1}$ Department of Biochemistry, Federal University Wukari, Nigeria \\ ${ }^{2}$ Department of Agricultural Economics and Extension, Federal University Wukari, Nigeria
}

Submission: October 12, 2016; Published: January 05, 2017

*Corresponding author: Ezeonu CS, Department of Biochemistry, Federal University Wukari, PMB 1020, Wukari, Taraba State, Nigeria,

Tel: +2348066919780; Email: chuksmaristos@yahoo.com

\begin{abstract}
Fermented foods are normally associated with health benefits. More often than not, emphases are made on the beneficial aspect of fermented food products such as: reduction of lactose to lactic acid for lactose intolerant individuals, increase in beneficial microorganism in human flora that safe guide the health of individuals by occupying space and inhibiting the multiplication of pathogens in the alimentary canal, increase in vitamins, mineral, protein and other nutrients and the ability to prevent deterioration and spoilage of most perishable foods by increasing their shelf life. There is no doubt that fermentation and its products have lots of benefits. However, the fact still remains that some of the microorganisms used in fermentation of food may become harmful under certain undesirable conditions.
\end{abstract}

Botulinum clostridium is an example of bacteria that causes poisoning in fermented foods and could be quite hazardous. Pre and post fermentation contamination of products may affect the physiology of the product thereby becoming disruptive to health and deleterious to life. Immuno compromised individuals may experience fatal diseases and even healthy individuals may not be spared when certain strains of microorganisms become involved in the fermentation processes. Biogenic amines and aldehydes which are biochemical indices of contamination in fermented foods may also result from healthy fermented foods thereby causing health related problems. Populations of the rural area are more associated with the production and consumption of fermented foods.

The levels of microbial and enzymic contaminants in fermented foods are most often low, such that they are not virulent enough to cause pathogenicity and ill health. This not withstanding, checks and quality control need to be part and parcel of production of fermented foods. This review, therefore, looks at the biohazards associated with major foods such as fermented products from meat, fruits, vegetables and milk products with a view to encouraging good quality control during production.

Keywords: Bacteria; Biogenic amines; Biohazard; Contamination; Fermented foods

\section{Introduction}

Fermented foods are food substrates that are invaded or overgrown by edible microorganisms whose enzymes, particularly amylases, proteases; lipases hydrolyze the polysaccharides, proteins and lipids to nontoxic products with flavors, aromas and textures pleasant and attractive to the human consumer [1]. If the products of enzyme activities have unpleasant odors or undesirable, unattractive flavors or the products are toxic or disease producing, the foods are described as spoiled [1]. Fermentation has been in use for centuries as a method through which food stuff are improved so as to increase palatability and improve the healthy factors from otherwise non healthy forms of raw foods. Westby et al. [2] explained that lesser developed countries require food processing technologies that are technologically appropriate, suitable for tropical regions and that are affordable in rural and urban economies.

In concodance to the above stated fact, Cooke et al. [3] stated that fermentation is a very important low cost food processing technique and a common means of preservation in lesser developed countries. Therefore, it serves as an alternative preservation method in place of highly expensive means such as refrigeration, canning, freezing and other such preservation techniques. Household level fermentation had been an ideal technology used in Nigeria, African countries and indeed world over for a wide range of food. The method used depends on the 
technology indigenous to the region. Range of food commodities fermentable includes cereals, dairy products, fish, meat, vegetables, fruits, legumes and root crops [4-7].

\section{Biohazards of fermented milk}

Filamentous moulds and yeast are common spoilage organisms of various food products such as fermented milk products, cheese, bread, stored crops and feed such as hay and silage [8]. Most of the fermented food product of milk origin such as cheese, nono and yorghut could be liable to pre-fermentation as well as post fermentation pathogenic exposures. The udder of the animal being milked and its surroundings, the container for milk collection, the air in the milking environment as well as the body part and clothing of the person milking these animals could constitute a strong repository for pre-fermentation infestation of the milk product with pathogenic bacteria such as disease causing bacteria. Thus, Charles [9] reported that milk produced under unhygienic conditions or from unhealthy cows may result in illness to humans. Milk from the time it leaves the udder until it is dispersed into containers for processing, everything it comes in contact with is a potential source of microorganisms. These include the air in the environment, the milking and storage vessels and the milking personnel.

During fermentation, as the lactic acid bacteria is carrying out the fermentation process, microorganism such as Escherichia coli, Salmonella paratyphi, Listeria monocytogenes, Brucellamelitensis and Clostridium botulinum may constitute potential hazard as they release bacterotoxins causing poisoning of the fermented milk products. For example when E. coli 0157:H7 is present in the milk, its numbers have been shown to multiply during the early stages of production of several cheese types, including hard cheeses, Camembert, cottage cheese and smear ripened cheese [10-14], an indication that pre- fermentation contamination is a great threat in fermentation of milk products. Post-fermentation contamination could also result due to the environment in which the milk product is fermented and inadequate protection of the fermented food from vermin and various pests that could become reservoir for introduction of pathogens (Figure 1).

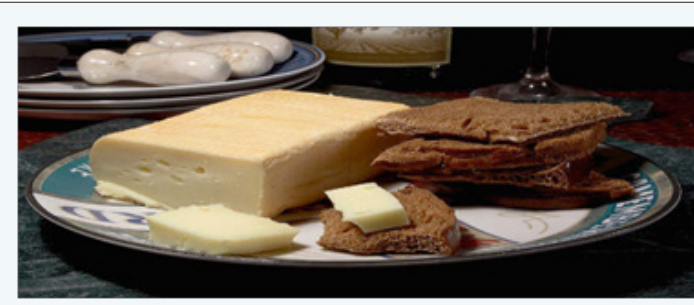

Figure 1: Limburger Cheese.

Limburger is probably the most famous of the smelly cheeses. One of the bacteria that creates human body odor is that same bacteria used to make Limburger. Source: Issa [15].

Spores of microbial sources such as from fungi could also cause post fermentation contamination. Inadequate hygiene during packaging could be another source of post fermentation contamination of these food products. Adebayo et al. [16] explained that several authors have also implicated yeasts such as Candida parapsilosis, Rhodotorulamucilaginosa, Kluyveromycesmarxians and Derbaromyceshansenii as common spoilage organisms of yoghurt and other fermented milk food products. Despite these identified dangers, fermented milk product is highly safe for consumption provided adequate hygienic precautions are maintained in the cause of producing these fermented products. According to D'Aoust et al. [17] and Getty et al. [18] in some outbreaks associated with fermented foods such as cheese and salami, the level of pathogen present in the implicated food has been very low and this may be due to the protective effects of fat.

In their survey of cheeses made solely from unpasteurized milk, they failed to find E. coli 0157:H7 in any of 801 samples tested and the species E. coli was undetectable $\left(<10 \mathrm{cfu} \mathrm{g}^{-1}\right)$ in $83 \%$ of samples. However, very high levels of E. coli ( $>105$ $\mathrm{cfu}^{-1}$ ) were found in a small proportion (1.4\%) of cheeses [19]. Thus Getty et al. [18] confirmed that if E. coli 0157:H7 is present in sufficient numbers, it is able to survive the fermentation and subsequent drying to a range of moisture to protein ratios. Despite the fact that fermented milk products are generally considered safe, hygiene during their production must be maintained. Adams \& Mitchell [20] explained that the idea that there is a certain threshold below which an organism cannot cause illness may apply to toxigenic pathogens where a certain population may be necessary to produce sufficient toxin to cause illness. In such cases, the risk assessment procedures will resemble those used to assess risk posed by chemicals. With infectious pathogens which multiply in the body, a single organism could in principle initiate an infection. Although the chances of infection from a single organism maybe very low, they cannot be neglected entirely, particularly in view of the low doses implicated in some outbreaks associated with fermented foods [18].

According to Yabaya et al. [21], Nono is made from local uncontrolled fermented cow milk which forms a major part of the staple food in Northern Nigeria. They are produced mainly by the nomadic Fulani. The fresh milk is directly obtained from a cow into a properly washed semi-dried calabash and kept wide open in the sun for approximately two hours to facilitate isolation of the fat layer. Some quantity of overnight fermented milk is added thereafter to serve as a starter culture and the inoculated fresh milk is left overnight at room temperature for fermentation to get sour milk known as "kindirmo" and the addition of large volume of water to the curdle sour milk which is then stirred with a T- shaped stick to a liquid of fine consistency gives rise to "Nono".

The most commonly product often mixed with nono is called "Fura" (a dumping made of millet or maize) to make a preparation called "fura da nono". In Nigeria, dairy by the Fulani is a family 
business operated at a subsistence level without any reference to quality control. Regardless of the method of preparation, the common practice among the female Fulani maiden hawkers is the addition of stream water and other products like the milkywhite supernatant of water soaked baobab tree referred to as "Kuka" to the fermented product. The reason for addition of the aforementioned is simply to increase the volume of the product and equally an attempt to improve taste and colour.

Investigation into the microbiology of nono revealed that the fermented product is basically a culture of Lactobacillus bulgaricus growing in association with Streptococcus thermophilus. The two organisms are mutually beneficial in the association with both organisms converting nearly the sugar to lactic acid producing only trace amount of bi- product. $S$. thermophile produces diacetyl and $L$. bulgaricus produces acetaldehyde [22]. Milk being a perishable commodity demands a strict hygienic control because it provides nutrients and near neutral $\mathrm{pH}$ (6.6), preferred by many micro-organisms and can as well serve as a growth medium for many pathogenic opportunistic micro-organisms [23].

S. thermophilus and L. bulgaricus are the known starter in milk fermentation that must be abundant and viable in the final fermented milk where apart from the acid production, equally adds to the fermented milk a significant flavor [24]. Microflora and fermented milk are specifically known to be basic ingredients for fermentation. Pathogenic bacteria in milk have been a major public health problem due to the number of diseases caused by them [25]. In Nigeria, it is a common phenomenon to find people relishing the Fulani fermented milk 'nono' without being bothered about the microbiological safety of such drink. Pasteurization as well as refrigeration before consumption on the part of the consumers is advised to protect them against pathogens and toxins associated with unhygienically prepared nono. The work carried out by Yabaya et al. [21] revealed that Staphylococcus species (100\%), Escherichia species (90\%), Streptococcus species (80\%), Bacillus species (40\%) and Klebsiella species (10\%) were isolated in the nono samples. They equally discovered that though, the coliform bacterial count was less in some samples, but nevertheless the presence of these bacteria identified is an indication that the fermented milk was feacally contaminated and this can pose a health hazard to the consumers of this fermented milk. Yabaya et al. [21], due to their findings called on the government and authorities concern to enlighten the populace, that is the nono sellers, on the health hazard associated with unhygienic processing of this milk so as to safeguard the health of the people.

\section{Fermented vegetables and fruits}

Fruits and vegetable fermentation is a means of preserving such fast perishable food crops. In areas such as the developing countries where crude method of agriculture is practiced, malnutrition manifests sooner than necessary in the populace due to unavailability or fast rate of perishing of the limited food produced. Vegetables and fruits are major components of human nutrition due to the abundance of the minerals and vitamins contained in them. Most illness in human population is as a result of mineral and vitamin deficiencies.

When harvested, fruit and vegetables undergo rapid deterioration, especially in the humid tropics where the prevailing environmental conditions accelerate the process of decomposition. There are many methods exploited for preserving fresh fruit and vegetables. Some of the preservation methods include: drying, freezing, canning and pickling (a method of vegetable and fruit fermentation with salt). However many of these are inappropriate for use on the small-scale in developing countries. For instance the canning of vegetables at the small-scale has serious food safety implications and contamination with botulism is a possibility. Costs are associated with freezing of fruits and vegetables which is not economically wise at the small-scale. However, a better alternative still remains the fermentation method which requires very little sophisticated equipment, either to carry out the fermentation or for subsequent storage of the fermented product. Fermentation is therefore a technique that has been employed for generations to preserve food for consumption at a later date and to improve food security. There are examples from around the world of the role fermented foods have played in preserving food to enhance food security [26].
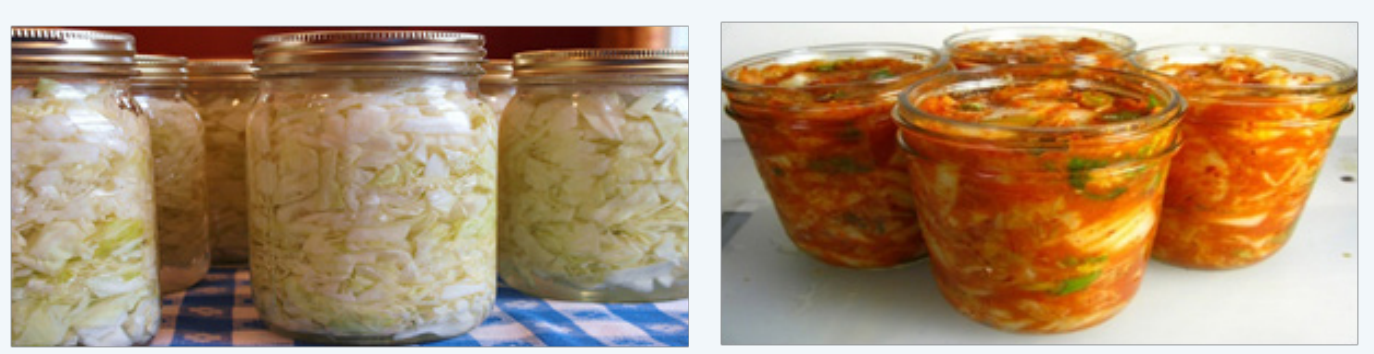

Figure 2: Fermented Cabbage (Sauerkraut) and staple food in Korea from fermented vegetables (Kimchi) [72].

Some of the fermented forms of vegetable have high nutritive values. Sauerkraut is produced from neatly shredded cabbage which has been allowed to undergo natural lactic acid fermentation in the presence of a small amount of salt. Most European countries especially those of the North and Eastern Europe, North America and Asia preserve cabbage in this form. 
Sauerkraut being high in vitamin C is consumed after cooking as a main course vegetable. It is reported to have mild laxative action due to it high content of dextran. The fermentation of sauerkraut is mainly by Leuconostoc mesenteroides especially during the first part of the curing period. Lactobacillus plantarum and Lactobacillus brevis completes the fermentation process of sauerkraut production. Good and neat cabbage will definitely give a good product. However, one of the hazards associated with Sauerkraut production is the growth of yeasts and mould at the surface where there is contact between the juice produced during fermentation and air. These usually cause product spoilage by causing off-odours and undesirable flavours (Figure 2)..

Fruit and vegetable pickles are produced by lactic acid fermentation and the products of alkaline bacterial fermentations. Pickled cucumbers are made in Africa, Asia and Latin America. FAO [26] service bulletin states that cucumbers undergo typical lactic acid fermentation and change from a pale product to a darker green and more transparent product. Khalpi is a cucumber pickle popular during the summer months in Nepal [27].

Pak-Gard-Dong is a fermented mustard leaf (Brassica juncea) product made in Thailand [26]. The FAO service bulletin explained that the mustard leaves are washed, wilted in the sun, mixed with salt, packed into containers for 12 hours. The water is then drained and a 3\% sugar solution added. They are again allowed to ferment for three to five days at room temperature. Micro-organisms associated with the fermentation include Lactobacillus brevis, Pediococcuscerevisiae and Lactobacillus plantarum [28].

According to FAO [25], service bulletin, green olives are placed in a $2 \%$ sodium hydroxide (lye) solution at $21{ }^{\circ} \mathrm{C}$ to 24 ${ }^{\circ} \mathrm{C}$ until the lye penetrates the flesh. Cold water is added to the solution, which dilutes the mixture until the lye is completely removed. The lye treatment is necessary to remove a bitter glucoside compound (oleuropein) from the outer tissues of the olive. Oleuropein is highly toxic to bacteria and therefore needs to be removed in order for a fermentation to take place. After the glucoside has been removed, the olives are placed in barrels with a 1 to $10 \%$ brine solution and allowed to undergo a spontaneous fermentation. The optimum fermentation temperature is $24^{\circ} \mathrm{C}$. The fermentation period usually takes between two and three months. Once fermentation is complete, the olives are packed in airtight jars and sterilised to give a good quality product with a long storage life.

Other pickled vegetables and fruits [26] includes: Nawmai-dong: pickled bamboo shoots (Bambusaglaucescens) from Thailand, Hom-dong: pickled red onions from Thailand, Jeruk: pickled vegetables including ginger and papaya from Malaysia, Pickled carrots and turnips produced in Asia and Africa (they are known as hua-chai po in Thailand and tai tan tsoi in China),
Nukamiso-zuke: vegetables fermented in rice bran, salt and water in Japan [6], banana pickles in the West Indies, fermented sweet peppers (torshifelfel) produced in west Asia and Africa, Cauliflower stalks are fermented to produce achartandal in India, Aubergines (torshibetingen) pickle in west Asia. Gundruk is obtained from the fermentation of leafy vegetables in Nepal. It is served as a side dish with the main meal and is also used as an appetiser. Gundruk is an important source of minerals particularly during the off-season when the diet consists of mostly starchy tubers and maize which tend to be low in minerals [27].

Pediococcus and Lactobacillus species are the predominant micro-organisms during gundruk fermentation. The fermentation is initiated by L. cellobiosus and L. plantarum, and other homolactics which make a vigorous growth from the third day onwards. Pediococcuspentosaceus increases in number on the fifth day and thereafter declines [27]. During fermentation, the $\mathrm{pH}$ drops slowly to a final value of 4.0 and the amount of acid (as lactic) increases to about $1 \%$ on the sixth day. As soon as the brine is formed, fermentation starts. As fermentation starts bubbles of carbon dioxide appear. Fermentation takes between one and four weeks depending on the ambient temperature and complete when no more bubbles appear $[29,30]$. Kawal is a strong smelling Sudanese, protein-rich food prepared by fermenting the leaves of a wild African legume, Cassia obtusifolia and is usually cooked in stews and soups [31]. It is used as a meat replacer or a meat extender. Its protein is of high quality, rich in sulphur amino acids which are usually obtained from either fish or meat [31].

In Zaire cassava leaves are fermented to produce ombolowakoba which is traditionally eaten with boiled cassava and plantain bananas [26]. Cassava leaves according to FAO [26] service bulletinare allowed to wilt and turn black in duration of about three to four days after which the cassava leaves are then chopped up and placed in a pot of boiling water for about one hour. During this processing stage, a water soluble extract of ash is produced by placing the ash of burnt dried banana skins and palm tree flowers in a strainer and pouring water through it. The extract is then added to the boiled cassava leaves. The extract is alkaline and neutralises the cyanhydric acid liberated when the leaves are chopped up [32]. Salt and dried fish or meat is also added. After allowing the cassava leaf mixture to cool a little, acidic palm oil is then added. This reacts with the excess alkali and neutralises it and makes it palatable as a desirable dish.

Dry salting is used for pickling many vegetables and fruits including limes, lemons and cucumbers. For dry salt pickling any variety of common salt is suitable as long as it is pure. Impurities or additives can cause problems [25] which include:

A. Chemicals to reduce caking should not be used as they make the brine cloudy.

B. Lime impurities can reduce the acidity of the final product and reduce the shelf life of the product. 
C. Iron impurities can result in the blackening of the vegetables.

D. Magnesium impurities impart a bitter taste.

E. Carbonates can result in pickles with a soft texture [29].

There are countless vegetable and fruit fermented products. Some will be briefly explained in this review so as to highlight the importance of this in the preservation and improvement of food quality and variety around the world. Thereafter, the few problems associated will be elaborated upon. From available literature it is obvious that the benefits of fermenting fruits and vegetable far outweigh the problems the technique may cause. This fact notwithstanding, the interest in this review is to point out the possible dangers inherent in fermented foods so as to increase awareness in quality control issues which will enhance safety in production processes and consumption.

Preservation of fruits are also not left out in this review, as, Louis Pasteur at the turn of the 19th Century during the boom of grape production in France solve the problem of fruit loss by devising means of converting healthy grapes in world acceptable juice forms popularly known as wine; a product of fruit fermentation. Due to this innovation, Asian, African and Latin American countries had devised method of preserving some fruits such as Mango pickle which is indeed very popular in these countries. Mango pickle is a major product of India, Pakistan and Bangladesh and it is estimated that the annual production of mango pickle in South Africa is over 10,000 tons [33]. FAO [26] explained that there are many fermented drinks made from fruit in Africa, Asia and Latin America. These include drinks made from bananas, grapes and other fruit. Grape wine is perhaps the most economically important fruit juice alcohol. It is of major economic importance in Chile, Argentina, South Africa, Georgia, Morocco and Algeria. Because of the commercialization of the product for industry, the process has received most research attention and is documented in detail (not of emphasis in this paper). Banana beer is probably the most wide spread alcoholic fruit drink in Africa and is of cultural importance in certain areas. Alcoholic fruit drinks are made from many other fruits including dates in North Africa, pineapples in Latin America and jack fruits in Asia. Dry salted lime pickles are made mainly in Africa and Asia particularly in North Africa, India and Pakistan.

A mixed fermentation of yeast followed by acetic acid bacteria action on alcohol and alcoholic sources give a product popularly known as vinegar. Another name for vinegar is sour wine which is one of the oldest products from fermented vegetables and fruits known to man. The acetic acid produced from fermented alcohol (ethanol) gives the characteristic flavor and aroma associated with vinegar.

FAO [25] stated that vinegar can be made from almost any fermentable carbohydrate source, for example fruits, vegetables, syrups and wine. The basic requirement for vinegar production is a raw material that will undergo an alcoholic fermentation. Apples, pears, grapes, honey, syrups, cereals, hydrolyzed starches, beer and wine are all ideal substrates for the production of vinegar. To produce a high quality product it is essential that the raw material is mature, clean and in good condition.

\section{Biohazards of fruit and vegetable fermentation}

Most traditional fermented products are made by natural fermentations carried out in a non-sterile environment. More to this, the method is difficult to control and there are risks of accompanying micro-flora causing spoilage and unsafe products. Some of the problems associated with fermented fruits and vegetables include:

A. The fermenting organisms, which are bacteria or yeasts, tend to be pathogenic and the ferment environment can easily breed pathogenic nematodes, protozoa and other harmful living organisms as fermentation in local settings last for upwards of two to three weeks especially the pit types of fermentation. Due to the unclean nature, one can never rule out the possibility of survival of harmful pathogenic microorganism despite the fact that the principle on which fermentation is based has to do with the positive fermenting microorganism suppressing the pathogens and the inability of most pathogens to survive in anaerobic environment. Thus for the fact that most fermented vegetable and fruit foods are not cooked before consumption, the survival of parasites, bacteria, fungi (moulds and spores/toxins) and possibly virus as found in raw foods are still components of fermented vegetables and fruits.

B. Cold nature of the fermented foods might not be in harmony with some individual's alimentary canals and may cause bowel upset.

C. The raw nature of fermented food as compared to cooked foods might affect digestion in some individual and cause $\mathrm{pH}$ imbalance in other individuals.

D. According to Wilson [34], aldehyde poisoning is common in fermented fruits and vegetables. Aldehydes are a type of organic chemical compound that are produced by some fermenting organisms. If the food is prepared correctly, aldehyde production should be minimal. However, more often than not, it is high in fermented food such as Kombucha tea, pickles and most fermented fruits. Aldehydes are quite toxic to the body, and this is a major problem with some fermented foods. On hair mineral test, individuals sodium/ potassium ratio starts to decline and gradually vitality is lost. The more aldehydes in a person's food the more the problem. The worst foods incriminated with high aldehyde contents according to Wilson [34] are: wine, beer, rejuvelac and kombucha tea and should be avoided as much as possible. The least content of aldehydes are found in foods 
such as miso and some good quality sauerkraut.

E. In comparison to cooked foods, fermented vegetables and fruits have non solubilized fibres which retain nutrients and prevent absorption. Nutrients in fermented vegetables for instance, are not concentrated and non available. Fermented vegetables are not warmed up and appear to cause discomfort to the digestive system, since the system is responsible for warming them up as well as churning activities and assimilation.

F. Fungi also play major role in the food industry. Moulds are often implicated in fruits and vegetable spoilage due to their massive bloom which introduces a lot of spores as well as toxins. The species most popular in undesirable changes in foods are the Aspergillus species. Their mold and those of other species can tolerate high concentration of salt and sugar. Moulds generally are not desirable in the fermentation of fruits and vegetable products.

G. Biogenic amines can also result in fermented vegetables especially commercial sauerkraut although the level is usually below what can be regarded as toxic. But the danger of long duration of exposure to human health cannot be ignored. Fruits such as raspberry juice have been implicated with sizeable quantity of amines egtyramine concentration.

\section{Biohazards of fermented meat}

Meat fermentation is a low energy, biological acidulation, preservation method which results in unique and distinctive meat properties such as flavour and palatability, colour, microbiological safety, tenderness, and a host of other desirable attributes of this specialized meat item. Changes from a raw meat to a fermented product are caused by "cultured" or "wild" microorganisms which lower the $\mathrm{pH}$. Since this is a biological system, it is influenced by many environmental pressures that need to be controlled to produce a consistent product. Some of these factors would include a fresh, low-contaminated, consistent raw material, a consistent inoculum, and strict sanitation, control of time, temperature, and humidity during production, smoke, and appropriate additives. Two of the three reported outbreak of food poisoning associated with fermented meats in the UK were caused by Salmonella [35,36] (Table 1).

Table 1: Fate of Salmonellae during Fermentation and Storage in Thueringer.

\begin{tabular}{|c|c|c|}
\hline Treatment & Influence & Due to \\
\hline $\begin{array}{c}\text { 18-24 hours, } \\
\text { fermentation }\end{array}$ & $\begin{array}{c}\text { Decreased } 0.75-5.4 \\
\operatorname{logs}\end{array}$ & Acidity and $\mathrm{NaCl}$ \\
\cline { 2 - 3 } & Little effect & $\begin{array}{c}\mathrm{NaNO}_{2}, \mathrm{NaNO}_{3} \text { and } \\
\text { ascorbic acid }\end{array}$ \\
\hline $\begin{array}{c}\text { Sucrose reduced } \\
\text { to 0.25\%, final } \mathrm{pH} \\
5.2-5.4\end{array}$ & Multiply & $\begin{array}{c}\text { Lack of sufficient } \\
\text { decrease in } \mathrm{pH}\end{array}$ \\
\hline $\begin{array}{c}\text { Heating } 46 \text { o } \mathrm{C}(115 \\
\text { oF })\end{array}$ & Multiply & $\begin{array}{c}\text { Insufficient } \\
\text { temperature }\end{array}$ \\
\hline
\end{tabular}

\begin{tabular}{|c|c|c|}
\hline $\begin{array}{c}\text { Heating } 52 \stackrel{\circ}{\circ} \mathrm{C}(126 \\
\text { of })\end{array}$ & Reduced number & $\begin{array}{c}\text { More effective in } \\
\text { both high and low } \\
\text { acid products }\end{array}$ \\
\hline Refrigerated storage & Declined & $\begin{array}{c}\text { Not sufficient for } \\
\text { complete destruction }\end{array}$ \\
\hline
\end{tabular}

Table 2: Hurdles in Fermented Meat for Pathogens.

\begin{tabular}{|c|c|}
\hline $\begin{array}{l}\text { Pathogens of } \\
\text { Fermented Meat }\end{array}$ & $\begin{array}{l}\text { How to overcome huddles to effective } \\
\text { fermentation. }\end{array}$ \\
\hline $\begin{array}{c}\text { General } \\
\text { pathogens }\end{array}$ & $\begin{array}{l}\mathrm{pH} \text {, bacteriocins produced by lactic acid bacteria, } \\
\text { antimicrobial substances by fungi, competition } \\
\text { for nutrients, nitrite, low oxygen, water activity } \\
\text { (aW), temperatures, smoking, cooking. }\end{array}$ \\
\hline Salmonella & $\begin{array}{l}\text { Nitrite, low oxygen level, } \mathrm{pH} \text {, water activity (aW) } \\
\text { to suppress thriving of Salmonella }\end{array}$ \\
\hline $\begin{array}{l}\text { Staphylococcus } \\
\text { spp. }\end{array}$ & $\begin{array}{l}\text { Poor competitor with lactic acid bacteria (e.g. } \\
\text { Lactocacillus) and starter staphylococci at } \\
\text { fermentation temperatures of } 20-25^{\circ} \mathrm{C}\left(68-77^{\circ} \mathrm{F}\right)\end{array}$ \\
\hline $\begin{array}{l}\text { Staphylococcus } \\
\text { aureus }\end{array}$ & $\begin{array}{l}\text { High fermentation temperatures may be a risk. } \\
\mathrm{pH} \text { of } 5.1 \text { and a water activity (aW) of } 0.86 \mathrm{in} \\
\text { aerobiosis and at a pH of } 5.7 \text { should be involved } \\
\text { to cause inhibition of pathogen }\end{array}$ \\
\hline $\begin{array}{l}\text { Bacillus and } \\
\text { Clostridium } \\
\text { spores }\end{array}$ & $\begin{array}{c}\text { Fermentation of sausages with lactobacilli and } \\
\text { water activity (aW) level of } 0.94-0.95 \text { causes } \\
\text { inhibition. }\end{array}$ \\
\hline $\begin{array}{l}\text { Listeria } \\
\text { monocytogenes }\end{array}$ & Some will survive, cooking may be necessary \\
\hline $\begin{array}{c}\text { Escherichia coli } \\
\text { 0157:H7 }\end{array}$ & Cooking is usually necessary to reduce it load. \\
\hline
\end{tabular}

Source: Modified from Erkkila [58]; Farber and Perkins [59].

Clostridium botulinum [37] (Table 2) is also a potential problem in fermented sausage but lactobacilli has been shown to have an inhibitory effect against $C$. botulinum. Also, this organism cannot multiply at a water activity (aW) level of $0.94-0.95$ [38].

Salmonella strains can be found in pork and poultry and can survive fermentation, but are usually only a problem when high water activity (aW) and $\mathrm{pH}$ are encountered (or when lethality has not occurred during drying). Fortunately, a rapid pH drop below 5.3 can be accomplished at temperatures above 18oC (64oF), which inhibit Salmonella growth. Lactobacilli have demonstrated inhibitory effects against Salmonella. Growing conditions are minimal at a $\mathrm{pH}$ of 5 with a water activity (aW) of 0.95. Salmonella inhibition is obtained by acidification in Northern Europe and by drying in Southern Europe [38].

Escherichia coli 0157: H7 and Listeria monocytogenes are ubiquitous, cold tolerant, and can survive fermentation. E. coli is found in both cattle and, to a lesser extent, in pigs and has been implicated in disease outbreaks linked to fermented meat since it can survive the fermentation process. Even though lactic acid production and drying can accelerate the destruction of $E$. coli, this is not always sufficient for total elimination. If E. coli 0157:H7 is present, even in low numbers, in the sausage batter, it can survive fermentation, drying, and storage. As few as 10 to 100 bacteria can cause serious illness. The U.S.D.A. FSIS regulations require a $5 \log$ reduction of $\mathrm{E}$. coli $0157: \mathrm{H} 7$ to produce a safe product when using beef in the formula and this is usually 
accomplished by heating [38]. Getty et al. [39] reported that one U.S. time temperature regulation for inactivation is $145^{\circ} \mathrm{F}(62.8$ ${ }^{\circ} \mathrm{C}$ ) for 4 minutes (United States Code of Federal Regulations.

Title 9 - Longer time and a lower temperature); also other temperature and effective duration for fermented meat treatment that are effective against these pathogens are: 8 hours at an internal temperature of $26.7 \stackrel{\circ}{\circ} \mathrm{C}(80 \stackrel{\circ}{\circ})$, then 24 hours at an internal temperature of $37.8^{\circ} \mathrm{C}\left(100^{\circ} \mathrm{F}\right)$ followed by 24 hours at an internal temperature of $43.3{ }^{\circ} \mathrm{C}\left(110^{\circ} \mathrm{F}\right)$. Tomicka et al. [40] suggest that lower temperature and longer fermentation time (European style) is better for elimination of 0157:H7 than higher temperature, shorter time (American style). It has also been suggested that lower $\mathrm{pH}$ during growth can confer cross protection against heat for 0157:H7 [41]. If heating is not practical, a low irradiation dose of $1.25 \mathrm{kGy}$ will also result in a 5 -log reduction [42]. Another possibility is to test and hold the final product or to hold a critical point that tests raw material, but also requires 2-log destruction. The International Commission on Microbiological Specification for Foods (ICMSF) recommends that up to 100 cells of L. monocytogenes per gram of fermented meat products can be tolerated [43,44]. L. monocytogenes is usually a problem when high water activity (aW) and $\mathrm{pH}$ are encountered but can grow at a pH between 4.6 and 9.6. However, this organism cannot grow below water activity (aW) levels of 0.90 [44]. These procedures recommended controlling E. coli 0157:H7, are also sufficient to control Trichina, Salmonella and Listeria [38]. Clostridium perfringens can often survive the typical fermentation process. Biogenic amines are low molecular weight compoundsthat are produced by microbial decarboxylation of amino acids or by amination and transamonification of aldehydes and ketones $[45,46]$. The raw material, starter culture, larger diameter product, storage temperature, and $\mathrm{pH}$ in fermented sausage production all encourage the production of biogenic amines. If starter cultures are tailored (e.g. mixed cultures usually are better than natural microflora) and processing conditions are controlled, formation of these undesirable amines can be controlled. Such amine compounds would include compounds such as histamine, tyramine (is an allergen), cadaverine, and putrescine, and some are health hazards and have been isolated from fermented products $[47,48]$.

The major amines isolated from fermented products are tyramine and putrescine and can combine with nitrites to form carcinogenic nitrosamines [49]. Enterobacteriaceae (produces histamine, cardaverine) and Pseudomonas which produces putrescine has been isolated from sausages and can produce biogenic amines particularly during the first days of fermentation [49-51]. However, it has also been speculated that amine-producing bacteria and/or amine formation can also occur after fermentation of dry sausages. Others speculate that amines can increase and then decrease in the latter state of aging [38].
A negative relationship between total biogenic amine and potassium sorbate concentration has been reported [52]. Some lactic acid bacteria such as Staphylococcus and Kocuria can also produce amines [53]. Other organisms that can be involved include enterococci, carnobacteria, pseudomonads, enterobacteria, micrococci caps, and a great number of lactic acid bacteria. Therefore, it is essential to use raw meat material, fermentation equipment/materials and starter cultures with as little contamination as possible. Suitable starter cultures can contribute to reduction of biogenic amines. Levels of biogenic amines in sausages can be controlled by reducing the microbial contamination of raw materials, high acidification, and by starter cultures such as Kocuriavarians, Staphylococcus xylous, Lactobacillus casei and L. plantarum [54-56].

Some surface molds and molds in black pepper can produce mycotoxins on the suface of the product. It is important if using mold stater cultures to select safe ones such as $P$. nalgiovense and P. chrysogenum [57-58], "House" microflora are a concern since this is a mixed culture. However, smoking, low water activity $(\mathrm{aW})$ and low $\mathrm{pH}$ of the product will also reduce mold growth [38].

\section{Huddles to effective meat fermentation}

Ockerman \& Basu [38] explained that public health and product spoilage will be a center focus of research in the future and a better understanding of the geological mechanisms will help tremendously. Hazard Analysis and Critical Control Point (HACCP) and hurdle technology control are becoming common place in the food industry and both are particularly important in fermented sausages. According to Ockerman \& Basu [38], the first hurdle in fermented products is the use of salt and nitrite in the formula, but, nitrite only has a major effect early in fermentation. Salt has a more prolonged hurdle as it assists in lowering the water activity $(\mathrm{aW})$. The next hurdle is the redox potential which is increased when air is incorporated during chopping therefore, vacuum chopping is often used. The addition of ascorbic acid or ascorbate, sugar, and micro-organisms using up oxygen, reduces this problem and is an additional hurdle. Next, competitive lactic acid bacteria must suppress undesirable organisms by lowering the $\mathrm{pH}$ and formation of bacteriocins. The final hurdle is a lowering of water activity (aW) during the ripening process and it steadily increases as the product dries. Since lactic acid bacteria are little affected by the hurdles, they have a selective advantage. Easily controlled fermentation chambers are gaining popularity to accurately control environmental conditions during processing $[59,60]$.

According to Steinkraus [61], the first principles behind safety of fermented food processes is that food substrates should be overgrown with desirable, edible microorganisms which therefore becomes resistant to invasion by spoilage, toxic or food poisoning microorganisms, as such, other, less desirable 


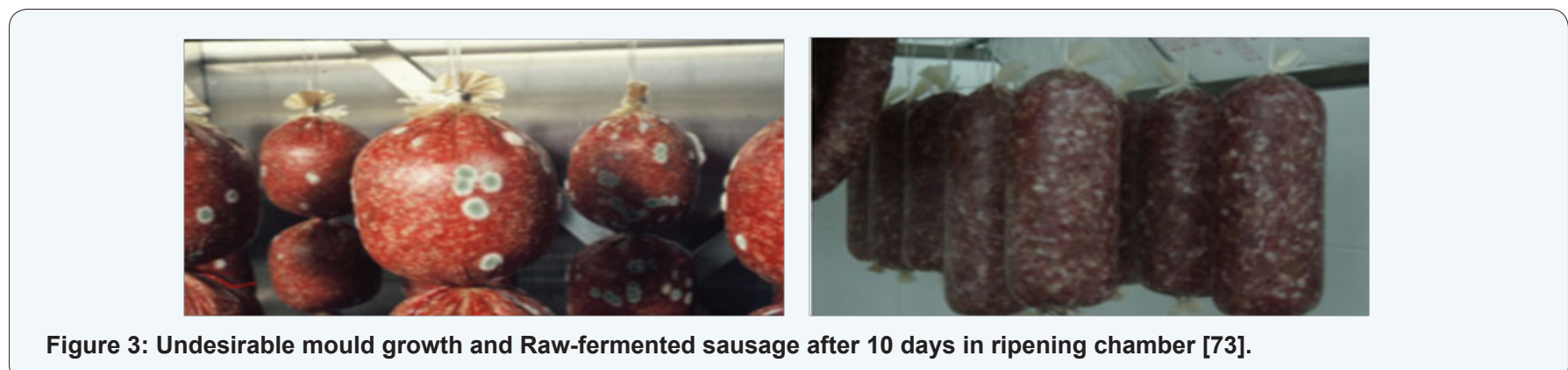

Typical raw-fermented sausages are uncooked meat products and consist of coarse mixtures of lean meats and fatty tissues combined with salts, nitrite (curing agent), sugars and spices as non-meat ingredients.

Ockerman \& Basu [38], concurred with this principle by Steinkraus [61] by suggesting that genetic determinants and transfer mechanisms could be utilized to develop superior lactic acid bacteria strains. These genetically modified microorganisms have the potential to improve food safety and quality, but they must be evaluated on a case-by-case basis. Genetic manipulation to "tailor-made" cultures to be used as starter cultures and fungal starter cultures are being evaluated for elimination of normal meat pathogen, toxin production, and regulation of fermentation including protolytic and lipolytic activity,and biopreservative properties. Muscle enzyme activity of a carcass, and its influence on meat quality, have been demonstrated [62]. Therefore, enzymes and genes can be used to select genetic lines of animals and raw materials for production of fermented sausages. In addition to lactic acid production, microorganisms with superior lipolytic and proteolytic capabilities will be sought to alter flavour.

For more value added fermented products, muscle protease, muscle and fat lipase (activities) and spice influence fermented sausage flavor [63-64]. If these can be altered, a flavour modification is probably possible. Ockerman \& Basu [38] stated that in the future, lactic acid bacteria may be used in meat products, which are not treated currently with starter cultures to add an additional hurdle and to improve fermented meat product safety; bacteriocins, with a bacteriocidal activity beyond fermentation have also been found effective against grampositive bacteria and in some cases gram-negative organisms. These could also be useful in fermentation as well as hurdles in meat products that are not currently fermented.

\section{Solution}

According to FAO [65], enzymes used in food processing have historically been considered non-toxic. Some characteristics arising from their chemical nature and source, such as allergenicity, activity-related toxicity, residual microbiological activity and chemical toxicity are, however of concern. These attributes of concern must, however, be addressed in light of the growing complexity and sophistication of the methodologies used in the production of food-grade enzymes. Safety evaluation of all food enzymes, including those produced by GM microorganisms, is essential if consumer safety is to be assured [66].

Contamination of the fermentation process can pose a major health risk in the final fermented product. Methodologies for identifying and monitoring the presence of chemical (pesticide residues, heavy metals, trace elements) and biochemical (aflatoxins) hazards in fermented foods are, therefore, a critical need [65]. There are movements toward implementing safetycontrol programmes such as the application of Hazard Analysis and Critical Control Point (HACCP) in food fermentations in many developing countries [65]. The application of HACCP necessitates the deployment of good agricultural practices, good manufacturing practices (GMPs) and good hygienic practices (GHPs) and the monitoring of critical control points for potential microbial and chemical contamination during bioprocessing [67]. Of global concern is the problem of mycotoxin contamination in foods, including fermented foods. Mycotoxin contamination is a major challenge in developing countries especially tropical areas such as in South Asia and Africa. FAO [65] international technical conference report mentioned that high-performance liquid chromatography (HPLC) and gas chromatography/mass spectrometry (GC/MS) are two of the most widely used methods for the detection and quantification of mycotoxins in developing countries. These methods, however, are time-consuming, difficult to use and require laboratory facilities. Therefore immunoassays that are economical in use, sensitive and easy to use would greatly facilitate the detection and quantization of mycotoxins in fermented food. A number of ELISA kits are now commercially available for the detection of aflatoxins, deoxynivalenol, fumonisins, ochratoxins, and zearalenone [68].

Suggested regulatory and policy issues for ensuring good fermentation processes by FAO [65] is outlined below:

A. Governments must be committed to protecting consumer health and interests, and to ensuring fair practices in the food sector.

B. There has to be consensus at the highest levels of government on the importance of food safety, and the provision of adequate resources for this purpose. 
C. Government policy that is based on an integrated foodchain approach is science-based, transparent and includes the participation of all the stakeholders from farm to table must be put in place.

D. The importance of the regional and international dimensions of the use of biotechnologies in food processing and safety must be recognized.

E. Priority must be accorded to promoting fermented foods in the food-security agendas of countries.

F. Governments must also provide an enabling environment that is supportive of the growth and development of upstream fermentation processes such as the production of high-value fermented products, such as enzymes, functionalfood ingredients and food additives.

\section{Conclusion}

While we discuss the health benefits of fermented foods, let us not lose sight of the possibility of toxins, pathogens and biogenic amines which could likely cause illness and death. This paper is by no means a way of discouraging the consumption of fermented food, but rather a critical look at the other aspect of fermentation which is quite neglected. Indeed there are limited literatures on the biological hazards associated with fermented foods. Perhaps this review will create awareness on the need for Hazard Analysis and Critical Control Point (HACCP) in food fermentations especially non commercial household fermentation popular in local environments all over the world.

Lot of studies has shown Japanese characteristics of extraordinarily high incidence in death by cardiovascular diseases, stomach cancer and hepatoma. This is not in isolation of the fact that they consume more fermented food stuff than other populations of the world. Most of such fermented foods were totally thought to be healthy until research were carried out to discover that some of those fermented product such as «miso", and «katsuobushi» as well as "sake" are not totally without negative aspects of toxin formation. Most of the African fermented fish as studied by Anihouvi et al. [69-71], have been implicated with several pathogen as shown in this review. Most of the fermented foods in different parts of the world such as Africa, Asia and South America need to undergo regular quality controls by scientists and health professional so as to safe guide the health of consumers.

Biogenic amines are low molecular weight compounds that are produced by microbial decarboxylation of amino acids or by amination and transamonification of aldehydes and ketones $[45,46]$. The raw material, starter culture, larger diameter product, storage temperature, and $\mathrm{pH}$ in fermented sausage production all encourage the production of biogenic amines. If starter cultures are tailored (e.g. mixed cultures usually are better than natural microflora) and processing conditions are controlled, formation of these undesirable amines can be controlled. Such amine compounds would include compounds such as histamine, tyramine (is an allergen), cadaverine, and putrescine, and some are health hazards and have been isolated from fermented products $[47,48]$. The major amines isolated from fermented products are tyramine and putrescine and can combine with nitrites to form carcinogenic nitrosamines [49]. Enterobacteriaceae (produces histamine, cardaverine) and Pseudomonas which produces putrescine has been isolated from sausages and can produce biogenic amines particularly during the first days of fermentation[49-51].

However, it has also been speculated that amine-producing bacteria and/or amine formation can also occur after fermentation of dry sausages. Others speculate that amines can increase and then decrease in the latter state of aging [38]. A negative relationship between total biogenic amine and potassium sorbate concentration has been reported [52]. Some lactic acid bacteria such as Staphylococcus and Kocuria can also produce amines [53]. Other organisms that can be involved include enterococci, carnobacteria, pseudomonads, enterobacteria, micrococci caps, and a great number of lactic acid bacteria. Therefore, it is essential to use raw meat material, fermentation equipment/materials and starter cultures with as little contamination as possible. Suitable starter cultures can contribute to reduction of biogenic amines. Levels of biogenic amines in sausages can be controlled by reducing the microbial contamination of raw materials, high acidification, and by starter cultures such as Kocuriavarians, Staphylococcus xylous, Lactobacillus casei and L. plantarum [54-56].

Some surface molds and molds in black pepper can produce mycotoxins on the surface of the product. It is important if using mold stater cultures to select safe ones such as $P$. nalgiovense and P. chrysogenum [56-57], "House" microflora are a concern since this is a mixed culture. However, smoking, low water activity $(\mathrm{aW})$ and low $\mathrm{pH}$ of the product will also reduce mold growth [38].

\section{References}

1. Steinkraus KH (2002) Fermentations in World Food Processing. Comprehensive reviews in food science and food safety: Inaugural Issue, Vol 1.

2. Westby A, Reilly A, Bainbridge Z (1997) Review of the effect of fermentation on naturally occurring toxins. Food Control 8(5\&6): 329339.

3. Cooke RD, Twiddy DR, Reilly PJA (1987) Lactic acid fermentation as a low cost means of food preservation in tropical countries. FEM Microbiol Rev 46: 369-379.

4. Steinkraus KH (1983) Handbook of Indigenous fermented foods. Marcel Dekker, New York, USA.

5. Steinkraus KH (1989) Industrialization of Indigenous fermented foods. Marcel Dekker, New York, USA.

6. Campbell-Platt G (1987) Fermented Foods of the World- a dictionary and guide. Butterworths, Boston, London.

7. Campbell-Platt G (1994) Fermented foods- a world perspective. Food Research International 27(3): 253-257. 
8. Filtenborg O, Frisvad JC, Thrane U (1996) Moulds in food spoilage. Int J Food Microbiol 2(4): 1-5.

9. Charles O (1986) Traditional cheese making manual. International livestock centre for Africa. Addis Ababa, Ethiopia, p. 1-2.

10. Arocha MM, Mc Vey M, Loder SD, Rupnow JH, Bullerman L (1992) Behaviour of enterohaemorrhagic E. coli 0157: H7 during manufacture of cottage cheese. J Food Prot 55(5): 379-381.

11. Reitsma CJ, Henning DR (1996) Survival of Enterohaemorrhagic E. coli 0157:H7 during the manufacture and curing of cheddar cheese. J Food Prot 59: 460- 464.

12. Ramsaran H, Chen J, Brunke B, Hill A, Griffiths MW (1998) Survival of bioluminescent Listeria monocytogenes and E. coli 0157:H7 in soft cheese. J Dairy Sci 81(7): 1810-1817.

13. Maher MM, Jordan KN, Upton ME, Coffey A (2001) Growth and survival of $E$. coli 0157:H7 during the manufacture and ripening of a smearripened cheese produced from raw milk. J Appl Microbiol 90(2): 201207.

14. Saad SMI, Vanzin C, Oliveira MN, Franco BDGM (2001) Influence of lactic acid bacteria on survival of E. coli 0157:H7 in inoculated Minas cheese during storage at $8.5 \mathrm{jC}$. J Food Prot 64(8): 1151- 1155.

15.Issa (2010) 18 Stinky Foods From Around the World.

16. Adebayo CO, Aderiye BI, Akpor OB (2014) Assessment of bacterial and fungal spoilage of some Nigerian fermented and unfermented foods. African J of Food Sci 8(3): 140-147.

17. D'Aoust JY, Warburton DW, Sewell AM (1985) Salmonella typhimurium phage-type 10 from cheddar cheese implicated in a major Canadian foodborne outbreak. J Food Prot 48(12): 1062-1066.

18. Getty KJK, Phebus RK, Marseden JL, Fung DYC, Kastner CL (2000) Escherichia coli 0157:H7 and fermented sausages: A review. J Rapid Methods Autom Microbiol 8(3): 141-170.

19. Ministry Of Agriculture, Fisheries and Food (MAFF) (2000) Report on a study of E. coli in unpasteurised milk cheeses on retail sale. Joint Food Safety and Standards Group Report No 8: 31.

20. Adams M, Mitchell R (2002) Fermentation and pathogen control: a risk assessment approach. Inter J Food Microbiol 79(1-2): 75- 83.

21. Yabaya A, Manga SS, Lucy M,Alhassan HM (2012) Bacteriological Quality of Fermented Milk Sold Locally In Samaru and Sabon-gari Market, Zaria-Nigeria. Continental J Microbiology 6(1): 14-18.

22. Schulz M, Hingst (1954) Chemistry of Yoghurt. Journal of Diary Science, pp. 330-336.

23. Vasvada PC (1988) Pathogenic bacteria in Milk .A review. Journal of Diary Science 71(10): 2809-2816.

24. Shanker PD (1980) S. thermophilus and L. bulgaricusin Fermented Milk. J Food Technol 15: 647-658.

25. Grant IR, Ball HJ, Rowe MT (1995) Inactivation of M. tuberculosis in Cow Milk at Pasteurization Temperature. In proceedings of the Fourth Internal Collegiums On Para tuberculosis, St John's College Cambridge, London, pp. 313-319.

26. Food and Agricultural Organisation (FAO) (1998) Fermented fruits and vegetables: A global perspective. In: Mike Battock et al. (Eds.), FAO of United Nations, Rome, Italy.

27. Karki T (1986) Some Nepalese Fermented Foods and Beverages, in "Traditional Foods: Some Products and Technologies", Central Food Technological Research Institute, India.

28. Boon-Lung N (1986) Traditional Technologies of Thailand: Traditional Fermented Food Products, in Traditional Foods: Some Products and Technologies, Central Food Technological Institute, India.
29. Lal G, Siddappa GS, Tandon GL (1986) Preservation of Fruits and Vegetables, Indian Council of Agricultural Research, India.

30. Kordylas JM (1990) Processing and Preservation of Tropical and Subtropical Foods. Macmillan, UK.

31. Dirar H (1992) Sudan's Fermented Food Heritage, in “Applications of Biotechnology to Traditional Fermented Foods", National Academy Press, USA.

32. Jones A, Hidellage V, Wedgewood H, Appleton H, Battcock M (1996) Food Processing, in "Biotechnology, Building on Farmers' Knowledge", In: Bunders J, (ED.).

33. Redelinghuys H, Van Der Riet W (1978) Green Mango Aachar, National Food Research Institute, Council for Scientific and Industrial Research, Pretoria, South Africa.

34. Wilson L (2013) Fermented Foods and why avoid most of them. Centre for Development.

35. Cowden JM, O'Mahoney M, Bartlett CLR, Rana B, Smyth B, et al. (1989) A national outbreak of Salmonella typhimurium DT 124 caused by contaminated salami sticks. Epidemiol Infect 103(2): 219-225.

36. O’Brien S, Lebaigue S (2002) CDSC, London, personal communication.

37. Goepfert JM, Chung KC (1970) Behavior of Salmonella during the manufacture and storage of a fermented sausage product. J Milk and Food Technol 33(5): 185-191.

38. Ockerman HW, Basu L (ND) Fermented Meat Products: Production and Consumption. The Ohio State University, Columbus, Ohio, USA.

39. Getty KJK, Phebus RK, Marsden JL, Schwenke JR, Kastner CL (1999) Control of Escherichia coli 0157:H7 in large $(115 \mathrm{~mm})$ and intermediate (90 mm) diameter Lebanon-style bologna. J Food Sci 64(6): 11001107.

40. Tomicka A, Jinru C, Barbut S, Griffiths MW (1997) Survival of bioluminescent Escherichia coli 0157:H7 in a model system representing fermented sausage production. J Food Protec 60(12): $1487-1492$.

41. Duffy G, Riordan DCR, Sheridan JJ, Call JE, Whiting RC, et al. (2000) Effect of $\mathrm{pH}$ on survival, thermotolerance, and verotoxin production of Escherichia coli 0157:H7 during simulated fermentation and storage. J Food Protec 63(1): 12-18.

42. United States Department of Agriculture (USDA) (1999) Irradiation of meat and products. Fed Reg 64(36): 9089-1013.

43. European Report. (1999) Opinion of the scientific committee on the veterinary measures relating to public health on Listeria monocytogenes. Office for Official Publication of the European commission. Health and Consumer Protection Directorate-General, Luxembourg, Europe.

44. AFSSA (2000) Agence Française de Sécurité Sanitaire des Aliments rapport de la commission d"etudes des risques lies a Listeria monocytogenes. Opinion of the scientific c o m m i t t e e on the veterinary measures relating to public health on Listeria momocytogenes, France.

45. Eerola S, Maijala R, Hill P (1992) The influence of nitrite on the formation of biogenic amines in dry sausages. Proceedings of Meat Science and Technology, Clermont-Ferrand, pp. 783-786.

46. Pipek P, Bauer F, Seiwald G (1992) Formation of histamine in vacuum packed fermented sausages. pp. 819-822.

47. Montel MC, Masson F, Talon R (1999) Comparison of biogenic amine content in traditional and industrial French dry sausages. Sci Alliments 19(2): 247-254.

48. Parente E, Martuscelli E, Gardini F, Grieco S, Crudele MA, et al. (2001) Evolution of microbial populations and biogenic amine 
production in dry sausages produced in Southern Italy J Appl Microbiol 90(6): 882-891.

49. Roig Sagues A-X, Hernandez-Herrero M, Lopez-Sabater EI, RodriguezJerez JJ, Mora-Ventura MT (1996) Histidine decarboxylase activity of bacteria isolated from raw and ripened salchichon, a Spanish cured sausage. J Food Protect 59(5): 516-520.

50. Marino M, Maifreni M, Moret S, Rondinini G (2000) The capacity of Enterobacteriaceae species to produce biogenic amines in cheese. Lett Appl Microbiol 31(2): 169-173.

51. Edwards RA, Dainty R, Hibbard CM (1987) Volatile compounds associated with the aerobic growth of some Pseudomonas species on beef. J Appl Bacteriol 57(1): 75-81.

52. Shalaby RA, Abd-El Rahman HA (1995) Effect of potassium sorbate on development of biogenic amines during sausage fermentation. Nahrung 39(4): 308-315.

53. Eerola S, Maijala R, RoigSagues A-X, Salminien M, Hirvi T (1996) Biogenic amines in dry sausage as affected by starter culture and contaminant amine-positive Lactobacillus. J Food Sci 61(6): 12431246.

54. Hui YH, Goddik LM, Hansen AS, Nip WK, Stanfield PS, et al. (2004) Handbook of food and beverage fermentation technology. Marcel Dekker, New York, USA, pp. 353-368, 385-458.

55. Fadda S, Vignolo GM, Oliver G (2001) Tyramine degradation and tyramine/histamine production by lactic acid bacteria and Kocuriastrains. J Biotechnol 23(24): 2015-2019.

56. Leuschner RG, Heidel M, Hammes WP (1998) Histamine and tryamine degradation by food fermenting microorganisms. Int. J. Food Microbiol 39(1-2):1-10.

57. Cook PE (1995) Fungal ripened meats and meat products in: Fermented Meats. Blackie Academic and Professional, London, UK, pp. 110-129.

58. Paska J (1995) Fungal toxins in raw and fermented meats: Fermented Meats Blackie Academic and Professional, London, UK, pp. 194216

59. Erkkila S (2001) Bioprotective and probiotic meat starter cultures for the fermentation of dry sausages. Academic dissertation, University of Helsinki, Department of Food Technology, p. 1-64.

60. Farber J, Perkins P (1991) Listeriamonocytogenes: a food pathogen Microbiol Rev 55(3): 476-511.
61. Steinkraus KH (1996) Handbook of Indigenous Fermented Foods. 2nd Edition Revised and Enlarged. Marcel Dekker, New York, USA, pp. 776.

62. Toldra F, Flores M (1989) The roll of muscle proteases and lipases in flavor development during the processing of dry-cured ham. Crit. Rev Food Sci 38(4): 331-352.

63. Fournaud J (1978) La microbiologie du saucisson sec. L"Alimentationet la vie. 64(2-3): 382-392.

64. Claeys E, De Smit S, Deieier D, Geiri R, Buys N (2000) Effect of rate of $\mathrm{pH}$ decline on muscle enzyme activities in two pig lines. Meat Science 57(3): 257-263

65. FAO (2010) Agricultural biotechnologies in developing countries Options and opportunities in crops, forestry, livestock, fisheries and agro-industry to face the challenges of food insecurity and climate change (ABDC-10): Current status and options for biotechnologies in food processing and in food safety in developing countries. International Technical Conference, Guadalajara, Mexico, 1 - 4.

66. Spok A (2006) Safety regulations of food enzymes. Food Technol Biotechnol 44(2): 197-209.

67. FAO (1995) FAO/WHO Guidance to Governments on the Application of HACCP in Small and/or Less-Developed Food Businesses. FAO Food and Nutrition Paper 86:1-74

68. SchmaleIII DG, Munkvold GP (2009) Mycotoxins in crops: a threat to human and domestic animal health. The Plant Health Instructor.

69. Anihouvi VB, Kindossi JM, Hounhouigan JD (2012) Processing and Quality Characteristics of some major Fermented Fish Products from Africa: A Critical Review. Inter Res J Biol Sci 1(7): 72-84.

70. Anihouvi VB, Sakyi-Dawson E, Ayenor GS, Hounhouigan JD (2009) Biochemical Changes and Aroma Development During the Spontaneous Fermentation of Cassava Fish into Lanhouin and Their Influence on Product Acceptability. J Aquatic Food Product Technol 18(4): 370384.

71. Anihouvi VB, Ayernor GS, Hounhouigan JD, Sakyi-Dawson E (2006) Quality characteristics of lanhouin: A traditionally processed fermented fish product in the Republic of Benin. AJFAND $6(1)$

72. http://www.homemademommy.net/

73. http://www.fao.org/docrep/010/ai407e/ai407e11.htm

Your next submission with JuniperPublishers
will reach you the below assets
- Quality Editorial service
- Swift Peer Review
- Reprints availability
- E-prints Service
- Manuscript Podcast for convenient understanding
- Global attainment for your research
- Manuscript accessibility in different formats
( Pdf, E-pub, Full Text, Audio)
- Unceasing customer service
Track the below URL for one-step submission
https://juniperpublishers.com/online-submission.php

